\title{
Social Work Intervention in the Education of Special Children
}

\author{
Jiaxu Wu \\ School of Politics and Administration \\ School of Wuhan University of Technology \\ Wuhan, China \\ 280028328@qq.com
}

\begin{abstract}
Social work is a kind of professional work guided by the values of altruism, based on scientific knowledge and aimed at social justice. In recent years, it has played an important role in the field of the education of special children abroad. Through the analysis of the current situation and theoretical basis of social work intervention in the education of special children, this paper puts forward the specific application and innovation of the case, group and community work methods in social work intervention in the education of special children, and points out the practical application procedures of the three social work methods in different situations, so as to make contributions to the development of the social work and the education of special children in China. The key point of this article is to put forward the innovative work ideas and methods for social work intervention in the education of special children.
\end{abstract}

Keywords-The education of special children; Superiority perspective; Empowerment theory; Social support theory; Social ecosystem theory

\section{INTRODUCTION}

Social work is a kind of professional work guided by the values of altruism, based on scientific knowledge and aimed at social justice. In the process of the continuous development of special education, the involvement of social work is an essentially important content to the development of special education based on the professional concept of helping people and self-help in social work at the same time. In the field of the education of special children abroad, social work has played a very important role. The development for the education of special children in China also urgently needs the intervention of social work. Therefore, it is urgent to study the intervention of social work in the education of special children.

\section{The Definition AND DEVELOPMENT STATUS FOR THE EDUCATION OF SPECIAL CHILDREN}

On June 10, 1994, it is said that "every child has its own unique identity, interest, ability and learning needs" on "The Salamanca Statement" of "World education conference on special needs" held by UNESCO; the design of education system and the implementation of education programs should take the wide differences of these characteristics and needs into account”. Special education and general education belong to a kind of education mode, but the objects of education are different. Ordinary education is faced with the normal development of children of childbearing age, while special educations faces children who are blind, deaf, and dumb, mentally retarded or have other mental and physical disabilities. In "The dictionary of special education terms" compiled and edited by UNESCO, special education is defined as "people who, through ordinary education method, cannot or hardly reach the age-appropriate education of their own, other levels of education form." Therefore, the education of special children refers to the education through the use of special methods to meet the learning needs of special children. Specifically, the education of special children can be divided into narrow and broad sense. From the narrow sense, the education of special children refers to the education mode for children and adolescents who have hearing, visual, mental retardation or physical disabilities. In a broad sense, the education of special children, in addition to containing the blind, deaf and dumb, mentally and physically disabled children's education age, includes intellectual or spiritual long abnormal children with learning disabilities.[1]

In "The outline of the national medium and long-term education reform and development plan (2010-2020)", it is explicitly required that "by 2020, the basic public education service system covering both urban and rural areas should be established to gradually realize the equalization of basic public education services". What's more, it pointed out particularly "Protecting the right to the education of people with disabilities". Special education, like general education, has been incorporated into the track of popularizing compulsory education for nine years. According to the National Bureau of statistics in 2007, "The second national disability sampling survey data bulletin (No. 2)" published in the second national disability sampling survey leading group, China's school-age children with disabilities from 6 to 14 years old is 2 million 460 thousand, which accounts for $2.96 \%$ of entire disabled population. In the school-age children with disabilities, $63.19 \%$ are receiving compulsory education in general education or special education schools. According to statistics, as of 2015, there are 2,053 special education schools nationwide with 442,200 students, which is not enough to meet the needs of community.[2]

Through the above data, we can see that a lot of problems also appear with the continuous development of the education of special children in China. How such a large group of special children receive good special education has become an important social problem, and the involvement of social work has become imperative. 


\section{THE THEORETICAL BASIS FOR THE INTERVENTION OF} SOCIAL WORK IN THE EDUCATION OF SPECIAL CHILDREN

\section{A. Advantage perspective and empowerment theory}

The dominant perspective is a kind of perspective that focuses on human internal strength and superior resources. The core idea is to believe that people are born with the ability to change their own abilities by using their own resources. Advantage perspective focuses on digging the potential of owner, helping the owner to realize its own advantages rather than just focus on their own problems and defects, so as to help owners to effectively respond to challenges in life and to solve the problem of owner. Empowerment theory refers to the continuous self-confidence and self-identity of individual in the process of positive interaction with others and environment, as well as increases the use of environmental resources to further help individuals to acquire more abilities.

Because of deficiencies in their functions, special children not only encounter various difficulties in life, but they also inevitably suffer from social prejudice and discrimination. Under the guidance of superiority, social workers think that although special children have certain physiological defects, they are not useful to society. There are always bright spots in them. For social workers, the purpose does not find the problem of the owner but explore the potential of owner from the daily life and magnify it. At the same time, it reduces the defects of owner, which is the purpose of achieving empowerment through the education for special children.[3]

\section{$B$. Social support theory}

Social support refers to the sum of certain social networks to use certain material and spiritual means to help the disadvantaged groups in society on voluntary basis. They can be classified into formal support and informal support. From the perspective of social support theory, if one person has stronger social support network, it is better to cope with various challenges from environment. Social work under the direction of social support theory emphasizes changing its role in personal life by intervening in the social network of individual, especially for those individuals with inadequate resources in social networks or using social networks. Social workers dedicate to helping them to expand social network resources for enhancing their ability to use social networks. The social network resources for special children are generally scarce. Social work intervention in the education of special children is to help them to formally link with many resources such as government, community and social organizations and the informal support for resources with family, friends and neighbors, expand their social support networks and enhance the utilization ability of social networks to better meet the challenges of life.[4]

\section{Social ecosystem theory}

The theory of social ecosystem takes "people in the situation" as the theoretical foundation, regard the social environment of human existence as a kind of social ecosystem and pay attention to the interaction of various systems between people and environment, so as to reveal the important effect of family and social system on personal growth. The theory of social ecosystem has the following two enlightenments on the education of special children: First, every special child is a member of society and is the main body of rights that cannot be ignored in promoting social fairness and educational equity. Both government and society have the responsibility and obligation to promote the development of the education of special children for meeting the educational needs of special children. Second, as a long-term systematic project, the education of special children is not only a government-led activity, but it also involves the integration of public resources and the participation of social forces. This is not only the responsibility of special education schools, but it also requires the coordination between family education and social education. Only by constructing the "school-family-society" education system can keep the sustainable development of special education.

\section{THE SPECIFIC METHOdS OF SOCIAL WORK INTERVENTION IN THE EDUCATION OF SPECIAL CHILDREN}

\section{A. The method of casework}

Casework refers to social workers that provide support and services for individuals or families who feel difficulties in an individualized way, to help individuals or families to solve problems, tap the potential of life and constantly improve the welfare level of individuals and society. The use of casework method in the education of special children can be carried out on the basis of collecting data, initial evaluating problems and needs, formulating and implementing plans and so on.

First, for the special individual children, social workers should give full play to the "four guides" role: The first is ideological guidance. We shall play the guiding role of social workers, help special children to adopt positive, healthy and upward ideas, correct learning attitude, correctly understand the importance of learning knowledge and skills for changing fate and meeting the requirements of society and form the rational world, life and values views; The second is the learning counseling. We should give full play to the role of "educator" of social workers, transfer knowledge and information and help special children to formulate proper career plans. We also shall help them to overcome learning disabilities and acquire appropriate learning methods and techniques. The third is the psychological counseling. We will give full play to the role of social workers as "psychological counselors" and provide prompt psychological counseling and psychological counseling on the psychological problems of children who are deprived of their professional skills due to long-term discrimination, anxiety, helplessness and confinement. We shall strengthen mental health education and carry out psychological intervention to help children with special new self-understanding, self-acceptance and self-identity formation; the fourth is the behavioral counseling. We shall give play to the role of social worker as "behavior corrector” and carry out tracking management and guiding for the special children who have hyperactivity, weariness and other deviant behavior in the process of learning to timely correct and reshape their health behaviors. Second, for special children's families, social workers also need to intervene in casework. According to the theory of ecosystem and the theory of cognitive behavior, before becoming a complete social person, special children must acquire the social mainstream 
rules and values through education and complete the personal socialization process. The earliest and most typical place is family in this process. The experience of some special education schools shows that those who deliberately or very well coordinate with the teaching work of school and receive guidance from school and family members who propose to educate their children in their own homes. The learning abilities, ideological status and personal growth other aspects have been significantly improved. The family system and family structure theory in the case social work model have a certain promotion effect on improving the relationship between special children and family members, and strengthening the participation of family education has certain promotion role.[5]

\section{B. Group working methods}

Group work refers to the working methods of changing the behavior of individual and recovering and developing social functions through the interaction and mutual assistance between the members of group with the help of social workers.

In the education of special children, social workers can use group work methods to act as "initiators", “organizers", "mentors", and "resource connections" and so on, so as to give full play to their roles. First, the special children who have common needs or problems can be divided into different groups, which are controlled by the different groups of 8-15 members. The purpose of self-help can be achieved through interaction and mutual assistance between the members of group. Such as groups with educational learning skills, exam responses, vocational skills training, groups with therapeutic interpersonal disorder counseling, psychiatric disorders, autism treatment, groups with growing emotional counseling and interest groups, groups with supportive poverty groups, etc.. Through the sharing, support, education and empathy of members in groups with each other during the interaction, they bring about changes in the cognition and behavior of members, acquire affective or instrumental support and establish a sense of community belonging and social support system; second, the same type of special children's family can be formed into mutual helping group. Through carrying out grouping work for the parents of special children, they can get informal support in the interaction with other parents who are facing similar problems. In the group of moderate size with similar nature and social function, sharing resources, sharing experience and encouraging each other among members can help to enhance confidence in education and rehabilitation.[6]

\section{The working methods of community}

Community work has broad and narrow sense. Broad community work refers to social services or social management that is carried out within the community to improve community welfare and promote the coordinated development of community and society. Narrow community work refers specifically to the theory, methods, skills and its application process of social work organizations and social workers in community work.

Social work emphasizes "people in the situation" and there is a kind of ecosystem relationship between human and environment. Special education institutions can be considered as a small community, so it is natural to apply the working methods of community to the education of special children. For community work method in the use of special education, first, we shall further strengthen institutional system and the construction of spiritual civilization to create a kind of positive and healthy campus cultural community atmosphere, so as to the special children are infected enjoy themselves. Second, we must mobilize and encourage special children to actively participate in social practice and second class and to participate in community service and volunteer activities. Through the two-way interaction between special children and their communities, they are encouraged to enhance their sense of social responsibility and take the initiative to integrate into society. They also use this as an opportunity to promote and educate community residents, so as to create "barrier-free" environment and alleviate the education of current special children and social exclusion problem for laying mass foundation; Third, social worker should actively link the social resources of their communities to special children, so that they can receive formal and informal support from community and help the development of special children and the education of special children.

\section{CONCLUSIONS}

The involvement of social work is an indispensable and important part to the development of special education for children. Social work involved in special education for children can both make major development in this process. Therefore, it is necessary to strengthen the theoretical study on social work involved in the education of special children and accelerate the substantive development of social work involved in the education of special children. This is of great significance to promoting social fairness and justice, safeguarding the legitimate rights and interests of citizens and building a harmonious and beautiful society.

\section{REFERENCES}

[1] Peng Xiaguang, On the Comprehensive Development of China's Special Education, Chinese Journal of Special Education, 2013,(11):3-7+13.

[2] Song Binfeng, Conceptual Analysis of Special Education and Individualized Education Program Implications, The Guide of Science \& Education, 2011,(08):21+23.

[3] Zhang Jie, Social work with blind, deaf children in special education-to Hohhot special education school as an example, Inner Mongolia Normal University, 2014.

[4] An Qiuling, On Social Work Intervention in Special Education for Children with Limited Abilities, Chinese Journal of Special Education, 2009,(03):13-16.

[5] Wang Bei, The mode of Play Therapy for Special Education School-Take Hohhot Special Education School as Example, Inner Mongolia Normal University, 2012.

[6] Chen Min, Study on Social Work Intervention in School Education for Hearing Impaired Children-Take a Special Education School in Hefei as an Example, Anhui University, 2017. 